ENTREPRENEURSHIP AND SUSTAINABILITY ISSUES

ISSN 2345-0282 (online) http://jssidoi.org/jesi/

2020 Volume 8 Number 2 (December)

http://doi.org/10.9770/jesi.2020.8.2(78)

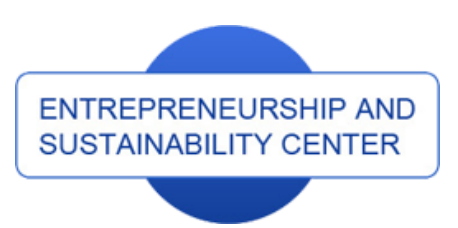

Publisher

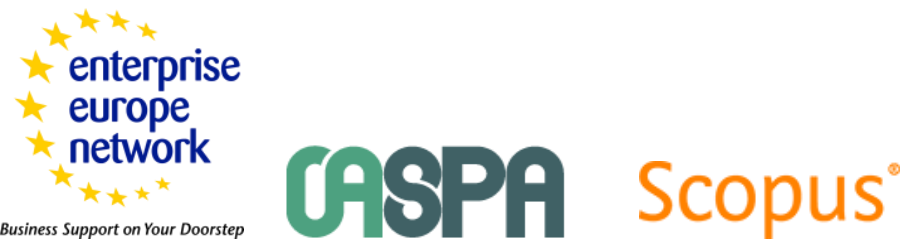

http://jssidoi.org/esc/home

1) Clarivate

Analytics

\title{
THE CONCEPT OF GLOBAL GOVERNANCE IN TOURISM FRANCHISES: A CASE STUDY OF TUI GROUP
}

\author{
Asad H. Aburumman \\ University of Sharjah, 27272 Sharjah, United Arab Emirates \\ E-mails: asadaburumman34@gmail.com
}

Received 15 May 2020; accepted 5 November 2020; published 30 December 2020

\begin{abstract}
The study characterizes the global corporate governance in the context of tourism. Risks the TUI Group would face during the implementation of the global governance strategy were assessed. The analysis of management and operational risks revealed that in conditions of global economic uncertainty tourism companies may use risk diversification to ensure flexibility. The risk likelihood assessment justified the need for the use of innovative management models with the aim of reducing the likelihood and impact of risks. An organizational-managerial framework for risk diversification was established that enables companies to cope with the global challenges in a synergistic effort. Finally, the study explored the socio-economic impact of global governance strategy on the competitive regional tourism
\end{abstract}

Keywords: global governance; international tourism business; risk diversification; tour operator; tourism franchising regional tourism; block-chain

Reference to this paper should be made as follows: Aburumman, A. H. (2020). The concept of global governance in tourism franchises: a case study of TUI group. Entrepreneurship and Sustainability Issues, 8(2), 1321-1339. http://doi.org/10.9770/jesi.2020.8.2(78)

JEL Classifications: L83, Z32

Additional disciplines: tourism, sociology

\section{Introduction}

Globalization has broadened the horizons of business markets, increased competition and technological advances. To achieve their presence on the global platform and stimulate international trade, organizations consistently make efforts to adopt global management tactics. It has become imperative for transnational organizations to be strategically effective by developing synergies between operations, capital and human resources (Bhullar, 2018).

In the aftermath of the 2008 financial crisis, discourses have emerged around variation in risk management, highlighting the interconnected role of business cycles, as well as derivative markets and geopolitical fragmentation (Han et al., 2019). Traditionally, the diversification process has been considered the most effective 


\section{ENTREPRENEURSHIP AND SUSTAINABILITY ISSUES}

ISSN 2345-0282 (online) http://jssidoi.org/jesi/

2020 Volume 8 Number 2 (December)

http://doi.org/10.9770/jesi.2020.8.2(78)

Make your research more visible, join the Twitter account of ENTREPRENEURSHIP AND SUSTAINABILITY ISSUES: @Entrepr69728810

way to reduce corporate risk (Sun et al., 2020). Implementation of a diversification strategy is a resource-intensive activity, therefore, determining the determinants of an effective strategy is necessary for global project managers to make more informed decisions in the management of companies (Shao et al., 2020).

The tourism services market transnationalizes in response to the current trends of the global tourism industry, giving room to international tourism complexes. National economies and social systems of different countries hence become interdependent and the international trade intensified. To regulate global problems in the tourism industry, international institutions were established that adapt relative standards and principles of international tourism.

The history of transnational tourism began in the mid 80-ies of 20th century with the internalization of the service industry (Skarga, 2018). A network marketing business model of interaction between tour operators and travel agents that was employed during that period allows acquiring a regular customer base and gaining control over the consumer market in remote destinations. Since the 90s, the network of tourist multinationals has been dynamically developing that are capable of effectively managing a set of tourism brands in the international tourism market as well as a tourism infrastructure (Dovgal, 2014). Under the auspices of tourism multinationals, an unrelated diversification strategy emerged (Duginets, 2017) that provides for the active cooperation with other industries such as food, retail, transport, media and information technology.

Transnationalization of the tourism market resulted in a tremendous growth in mergers and acquisitions (M\&A) at the end of 90s (horizontal integration) (Dangi \& Jamal, 2016). The consolidation of tourism entailed regional expansion and the emergence of conglomerate structures with related diversification (vertical integration). The restructuring of the global tourism industry took place with the penetration of new industries such as transport, banking, insurance, advertising, trade, and production. Furthermore, new destinations were introduced. In the context of globalization, European and British tour operators like TUI (Germany), Thomas Cook (Germany), My Travel (UK), Rewe Touristic (Germany), First Choice (UK), Kuoni (Switzerland), Grupo Iberostar (Spain), Club Med (France), Alltours (Germany), and Hotelplan (Switzerland) serve as an example of vertical and horizontal integration (Skarga, 2018). At the end of the 20th century, these companies acquired dominance in the European tourism market.

TUI Group is a German travel company, originated from the industrial and transportation organization. In the mid-nineties, the company turned its gears towards tourism and shipping, partly selling its industrial groups to acquire several large travel and transport companies. After the merger with a British subsidiary of TUI Travel in 2014, TUI Group became the world's largest travel business: many tour operators with leading positions in their own domestic markets are gathered under its roof. In Germany, they include TUI Deutschland, 1-2-FLY, airtours and Wolters Reisen; in the UK, Thomson and First Choice. TUI operators are also among the leading national brands in Austria, Poland, Switzerland, Denmark, Finland, Norway, Sweden, France, Belgium, the Netherlands, China, Russia and Ukraine. The TUI Group's Global governance Strategy drives on four specific strategic initiatives (Tui Group, 2019a).

Markets \& Airlines: maintain strong market positions. In 2019, Markets \& Airlines business experienced a number of external challenges such as potential Brexit and two 737 MAX crashes in Indonesia and Ethiopia. These events, the Boeing 737 MAX ban specifically, caused an $85 \%$ reduction of net profit in the third quarter of 2019. Therefore, the company's strategic goals were market consolidation in the Markets \& Airlines sector and solution to structural problems. The company seeks to improve flexibility and cost position, facilitate innovation, and promote centralized IT processes. These initiatives will enable the expansion of product offering beyond 


\section{ENTREPRENEURSHIP AND SUSTAINABILITY ISSUES}

ISSN 2345-0282 (online) http://jssidoi.org/jesi/

2020 Volume 8 Number 2 (December)

http://doi.org/10.9770/jesi.2020.8.2(78)

Make your research more visible, join the Twitter account of ENTREPRENEURSHIP AND SUSTAINABILITY ISSUES: @Entrepr69728810

accommodation-only packages while remaining competitive, maintaining the leading market positions, and supporting the airline asset management system.

Hotels \& Cruises: expansion at scale, driving returns by benefiting from vertical integration. With 411 hotels, TUI Group has built a large and highly profitable hotel business (with a return on invested capital of 14\%). Hotels \& Cruises business is closely linked to Markets \& Airlines by virtue of benefits from vertical integration. According to the company's strategic plans, TUI will continue to invest in portfolio expansion and risk diversification through joint venture structures. It is planned to accelerate the growth of the TUI Blue brand to 100 hotels by the end of 2020 using a franchise partnership system. The key investment focus area are the Caribbean, South East Asia and Africa.

GDN-OTA platform: building a digital distribution platform based on competitive pricing to attract consumers. The new strategy relates to new markets: China, India and Brazil. The platform will focus on the asset-light business model. As the hotel and cruise portfolio grows, the TUI expands its digital capabilities. The company has ambitious plans for engaging hotels that previously had no collaborative relationships with it. TUI plans to surpass its competitors by offering attribute-based booking services and expanding the range of service offering to meet customer likings. Since the global hotel chains are accustomed to this technology, TUI may benefit from cooperating with the spa industry. The strategic goal of company's CRM system is to position TUI as a holistic digital hotel service provider by 2022.

Destination experiences platform: building scale in the 'things to do' market. The tours and activities market annually grows approx. 7\% with a sales volume of around 150 billion euros. In this market, TUI has built a growing platform business with an impressive range of local tourism products. The TUI business model is based on a two-sided open platform that is accessible for direct booking, distribution colleagues and third parties (i.e., travel services suppliers), connecting company's destination experiences products.

With further growth of the information space, businesses need to improve their business practices and methods as well as to find effective ways of gaining competitive advantages. Organizational-managerial innovations based on online platforms and new forms of partnerships impel international tourism networks towards capacity strengthening.

This paper aims to examine the TUI Group strategy for global governance in the regional context. The following objectives were set to facilitate the achievement of this aim:

- Characterizing global governance within the context of corporate interactions.

- Exploring organizational and managerial risks of implementing TUI Group strategy for global governance.

- Assessing the likelihood of global and local risks the TUI Group may face with.

- Finding organizational and managerial solutions to reduce the likelihood of these risks materializing and eliminate their destructive impact.

- Building a blockchain-based organizational model of global governance in the tourism business.

Indentifying the socio-economic impact of the Global Governance Strategy on the competitive regional tourism. 
ENTREPRENEURSHIP AND SUSTAINABILITY ISSUES

ISSN 2345-0282 (online) http://jssidoi.org/jesi/

2020 Volume 8 Number 2 (December)

http://doi.org/10.9770/jesi.2020.8.2(78)

Make your research more visible, join the Twitter account of ENTREPRENEURSHIP AND SUSTAINABILITY ISSUES: @Entrepr69728810

\section{Materials and methods}

Exploring official statistics on the company's performance and development strategy as well as current trends of the global tourism industry, risks of implementing the TUI Group Strategy for Global governance were determined and a diversification solution was found. Methodology for the risk impact assessment consists of four steps: risk identification, risk description, risk assessment and organizational-managerial solution.

Risk identification: management identifies the risks relevant to the pursuit of the strategy within their business area in the context of four risk types, i.e., long-term strategic and emerging threats; medium-term challenges associated with business change; short-term risks due to changes in the external and regulatory environment; and short-term risks associated with internal operations and control.

Risk description: concerns in relation to risks are identified; causal factors that may result in the risk materializing and potential consequences if it does are determined. This allows evaluating the interaction of risks and potential triggers before developing mitigation strategies for causes or consequences.

Risk assessment: The main advantage of assessing the gross risk is that it highlights the potential risk exposure if mitigation fails completely or takes no place at all. Both impact and likelihood are ranked using the criteria given in Table 1.

Table 1. Risk assessment criteria

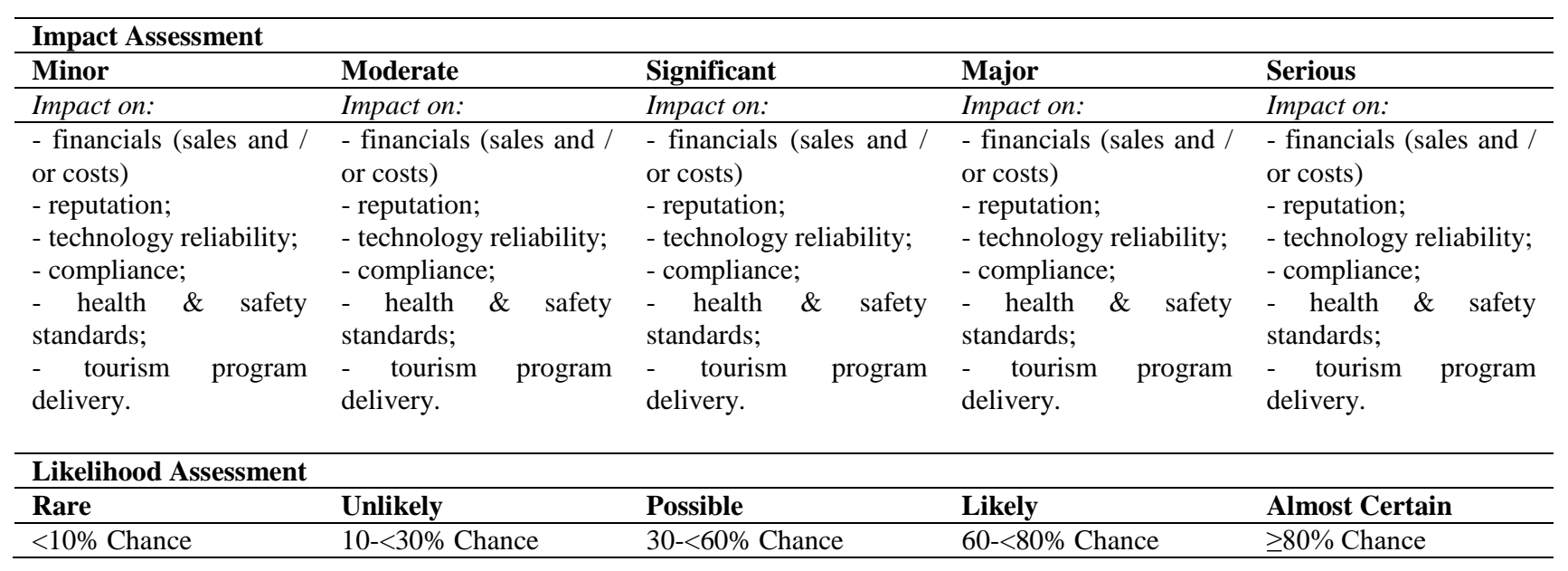

Source: Developed by the authors based on Tui Group (2019b).

The next step is to assess and document the mitigation to reduce the likelihood of the risk materializing and its impact on company's performance if it does.

Organizational-managerial solution: If the management assesses the current risk score too high, an action plan will be drawn up with the aim of introducing new or stronger measures to reduce the impact and/or likelihood of the risk. 
Make your research more visible, join the Twitter account of ENTREPRENEURSHIP AND SUSTAINABILITY ISSUES: @Entrepr69728810

Details on the likelihood and impact of the principal risks to the TUI Group as well as organizational-managerial solutions for their reduction are shown in Figure 1. In the risk assessment, the current risk position relates to the current level of risk faced by TUI and triggered by challenges in the global tourism industry. The target risk position shows the target level of risk after implementing an organizational-managerial mitigation solution. Table 2 showcases a risk management technology relevant to the corporate strategy of the TUI Group.
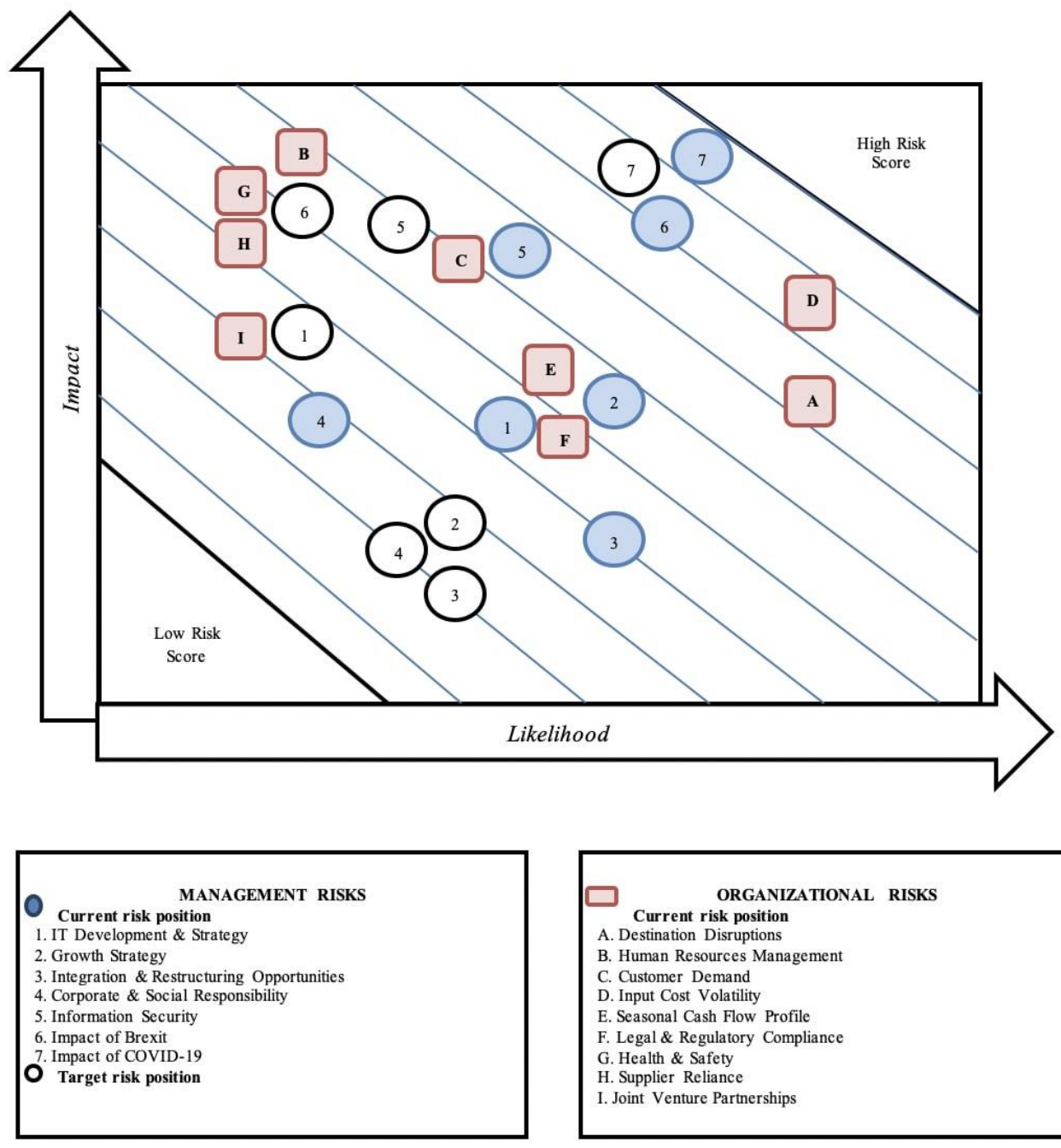

\section{ORGANIZATIONAL RISKS}

Current risk position

A. Destination Disruptions

B. Human Resources Management

C. Customer Demand

E. Seasonal Cash Flow Profile

F. Legal \& Regulatory Compliance

G. Health \& Safety

. Supplier Reliance

I. Joint Venture Partnerships

Figure 1. Management and organizational risks to TUI Group, adapted from Tui Group (2019a, 2019b, 2019c) 
ENTREPRENEURSHIP AND SUSTAINABILITY ISSUES

ISSN 2345-0282 (online) http://jssidoi.org/jesi/

2020 Volume 8 Number 2 (December)

http://doi.org/10.9770/jesi.2020.8.2(78)

Make your research more visible, join the Twitter account of ENTREPRENEURSHIP AND SUSTAINABILITY ISSUES: @Entrepr69728810

Table 2. Risk management under the global governance strategy, adapted from Tui Group (2019a, 2019b, 2019c)

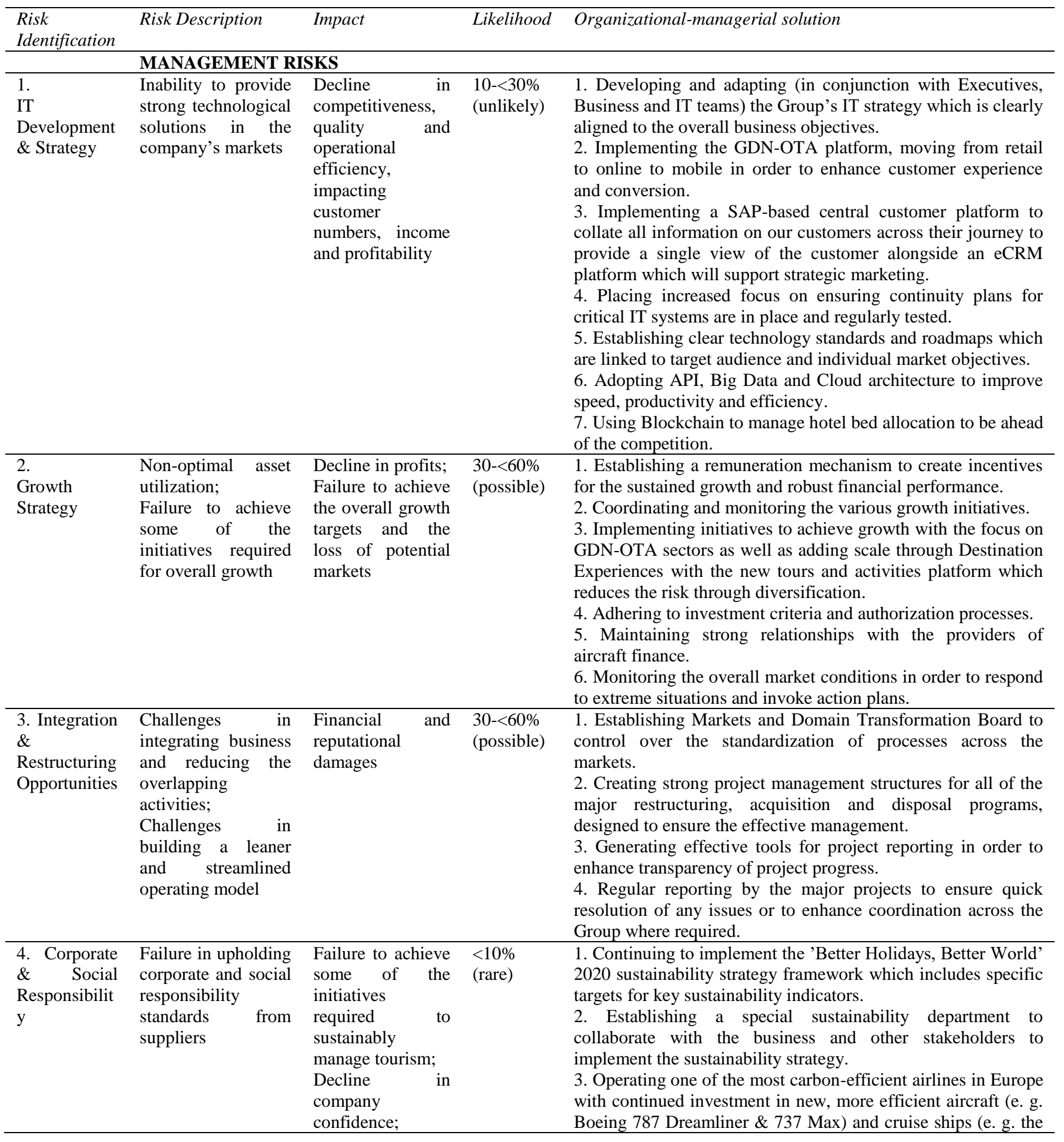


ENTREPRENEURSHIP AND SUSTAINABILITY ISSUES

ISSN 2345-0282 (online) http://jssidoi.org/jesi/

2020 Volume 8 Number 2 (December)

http://doi.org/10.9770/jesi.2020.8.2(78)

Make your research more visible, join the Twitter account of ENTREPRENEURSHIP AND SUSTAINABILITY ISSUES: @Entrepr69728810

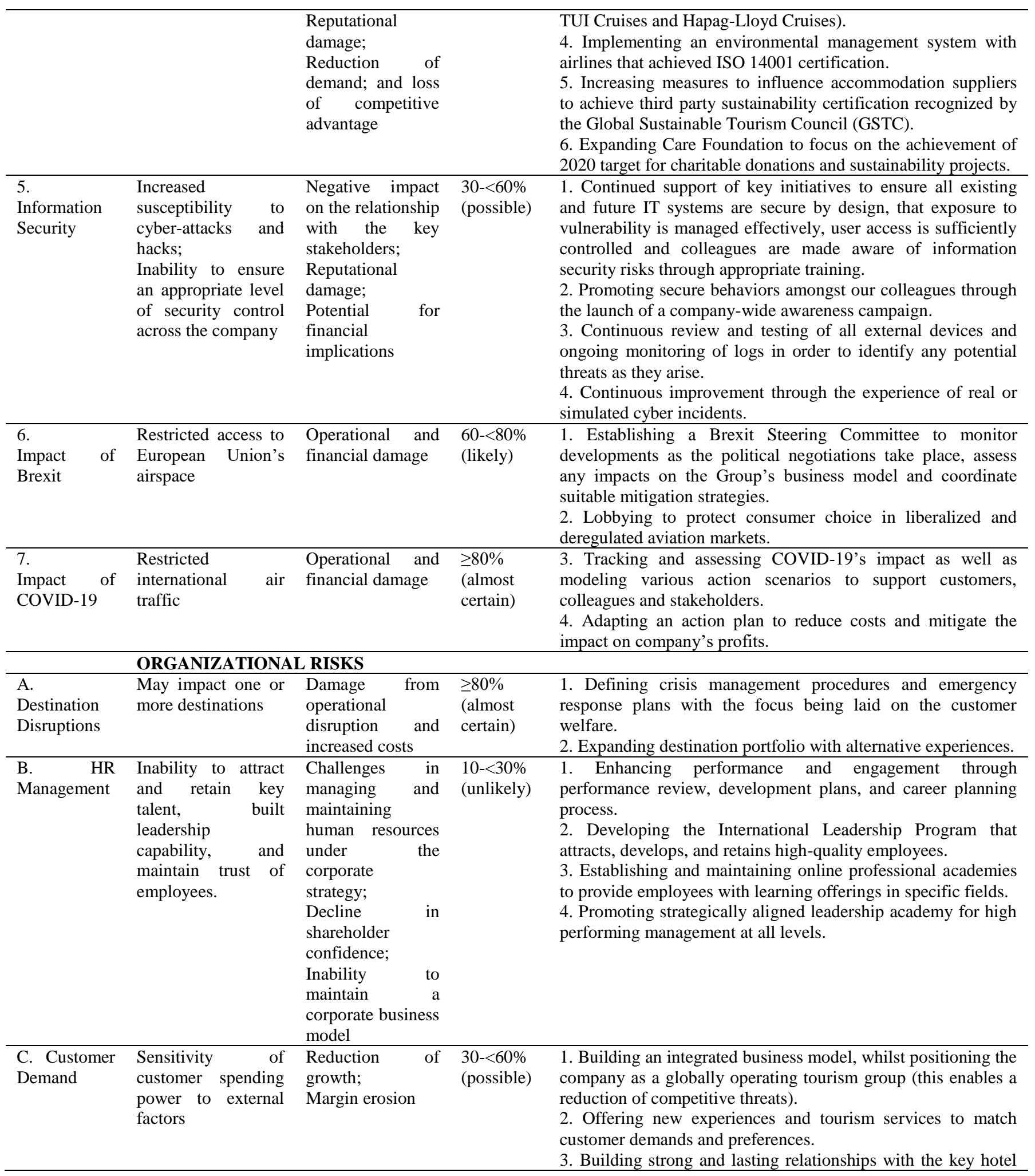


ENTREPRENEURSHIP AND SUSTAINABILITY ISSUES

ISSN 2345-0282 (online) http://jssidoi.org/jesi/

2020 Volume 8 Number 2 (December)

http://doi.org/10.9770/jesi.2020.8.2(78)

Make your research more visible, join the Twitter account of ENTREPRENEURSHIP AND SUSTAINABILITY ISSUES: @Entrepr69728810

\begin{tabular}{|c|c|c|c|}
\hline $\begin{array}{l}\text { D. Input Cost } \\
\text { Volatility }\end{array}$ & $\begin{array}{l}\text { Inability to } \\
\text { adequately manage } \\
\text { the volatility of } \\
\text { exchange rates, fuel } \\
\text { prices and other } \\
\text { input costs; A rigid } \\
\text { hedging policy; } \\
\text { Change } \\
\text { macroeconomic } \\
\text { conditions }\end{array}$ & $\begin{array}{lr}\text { Increased } & \text { costs } \\
\text { and } & \text { margin } \\
\text { erosion; } & \\
\text { Inability } & \text { to } \\
\text { respond } & \text { to } \\
\text { competitive } \\
\text { pricing pressures } \\
\text { during the season; } \\
\text { Impact on } \\
\text { exchange rates } \\
\text { and the translation } \\
\text { of market results } \\
\text { into the reporting } \\
\text { currency. }\end{array}$ & $\begin{array}{l}60-<80 \% \\
\text { (likely) }\end{array}$ \\
\hline $\begin{array}{l}\text { E. Seasonal } \\
\text { Cash Flow } \\
\text { Profile }\end{array}$ & $\begin{array}{l}\text { Inability to } \\
\text { adequately manage } \\
\text { cash balances in the } \\
\text { winter low season }\end{array}$ & $\begin{array}{l}\text { Inability to to } \\
\text { settle liabilities as } \\
\text { they fall due } \\
\text { whilst ensuring } \\
\text { that financial } \\
\text { covenants are } \\
\text { maintained }\end{array}$ & $\begin{array}{l}30-<60 \% \\
\text { (possible) }\end{array}$ \\
\hline
\end{tabular}

partners to develop new concepts.

4. Using scale to reduce costs and make prices competitive.

5. Market diversification in order to reduce the exposure to one particular economic cycle.

6. Promoting the benefits of travelling with a sustainable globally-operating tour operator to increase customer confidence.

1. Using the appropriate derivative financial instruments to provide hedging of the underlying transactions with fuel and foreign currency.

2. Maintaining an appropriate hedging policy to ensure that the hedging cover is taken out ahead of the customer booking profiles.

3. Tracking the foreign exchange and fuel markets to ensure the appropriateness of the hedging policies.

\begin{tabular}{llrlrl}
\hline F. Legal \& & Non compliance & Fines or other & $30-<60 \%$ \\
Regulatory & with laws and & sanction from & (possible) \\
Compliance & regulations & regulatory bodies &
\end{tabular}

1. Ensuring an even distribution of profit and cash profile across the year.

2. Producing short-term and long-term cash forecasts during the year to manage cash resources effectively.

3. Implementing a financial policy which leads to an improvement in the credit rating and makes it easier to maintain financing capabilities.

4. Maintaining high-quality relationships with the key financiers and monitoring compliance with the financial covenants.

5. Raising additional finance from the capital markets when required.

1. Communication and strong position of management regarding the compliance with laws and regulations.

2. Establishing Legal Compliance Committee to ensure appropriate oversight, monitoring and action plans and to further improve the compliance effort across the Group.

3. Embedding legal and tax expertise in all major businesses responsible for maintaining high quality relationships with the relevant regulators and authorities.

4. Ongoing implementation and review of Compliance Management System to monitor compliance with regulations and provide expert advice to local teams on specific compliance areas..

\begin{tabular}{|c|c|c|c|c|}
\hline $\begin{array}{l}\text { G. Health \& } \\
\text { Safety }\end{array}$ & $\begin{array}{l}\text { The occurrence of } \\
\text { accidents or } \\
\text { incidents causing } \\
\text { illness, injury or } \\
\text { death to customers } \\
\text { or colleague on a } \\
\text { trip }\end{array}$ & $\begin{array}{l}\text { Reputational } \\
\text { damage and/or } \\
\text { financial } \\
\text { liabilities through } \\
\text { legal action being } \\
\text { taken by the } \\
\text { affected parties }\end{array}$ & $\begin{array}{l}<10 \% \\
\text { (rare) }\end{array}$ & $\begin{array}{l}\text { 1. Establishing health and safety functions in all businesses in } \\
\text { order to ensure an appropriate focus on health and safety } \\
\text { processes as part of the operating activity. } \\
\text { 2. Ongoing monitoring to ensure compliance with minimum } \\
\text { standards. } \\
\text { 3. Putting appropriate insurance policies to action. }\end{array}$ \\
\hline $\begin{array}{l}\text { H. Supplier } \\
\text { Reliance }\end{array}$ & Failure in suppliers & $\begin{array}{l}\text { Inability to } \\
\text { continue the core } \\
\text { operations }\end{array}$ & $\begin{array}{l}<10 \% \\
\text { (rare) }\end{array}$ & $\begin{array}{l}\text { 1. Using reputable and financially stable suppliers, particularly } \\
\text { in areas where a single supplier is used to provide a service. } \\
\text { 2. Regular monitoring of supplier performance against agreed } \\
\text { terms and conditions. }\end{array}$ \\
\hline
\end{tabular}


ENTREPRENEURSHIP AND SUSTAINABILITY ISSUES

ISSN 2345-0282 (online) http://jssidoi.org/jesi/

2020 Volume 8 Number 2 (December)

http://doi.org/10.9770/jesi.2020.8.2(78)

Make your research more visible, join the Twitter account of ENTREPRENEURSHIP AND SUSTAINABILITY ISSUES: @Entrepr69728810

3. Building strong working relationships with all key suppliers. 4. Attracting more owned and joint venture partner hotels that form a substantial part of the risk reduction program.

5. Establishing a robust prepayment authorization process to both limit the level of prepayments made and ensure that they are only paid to trusted, credit-worthy counter-parties.

6. Monitoring prepayments to effectively manage financial risks.

\begin{tabular}{lllll}
\hline $\begin{array}{l}\text { I. Joint } \\
\text { Venture }\end{array}$ & $\begin{array}{l}\text { Failure of good } \\
\text { relationships with } \\
\text { key partners; }\end{array}$ & $\begin{array}{l}\text { Operational } \\
\text { difficulties and } \\
\text { jeopardized }\end{array}$ & $\begin{array}{l}<10 \% \\
\text { (rare) }\end{array}$ & $\begin{array}{l}\text { 1. Maintaining good working relations with the main joint } \\
\text { venture partners as well as commitment to the growth strategy }\end{array}$ \\
& $\begin{array}{l}\text { Inconsistency of } \\
\text { business objectives }\end{array}$ & $\begin{array}{l}\text { achievement of } \\
\text { financial targets }\end{array}$ & \\
\hline
\end{tabular}

\section{Results}

Current and potential risk management is critical to the long-term success of business and integral to corporate management. The process of risk identification, assessment and response is continuous and embedded within the company's operations. It is consolidated, reported and reviewed at varying levels of corporate management on a quarterly basis. This study divides the principal risks to the Group into management and operational subcategories.

Management risks to TUI Group (Tui Group, 2019c):

1. IT Development \& Strategy. The Group aims to improve customer experience by providing appealing and continuous customer service through delivery of digital solutions, innovative platform capabilities, underlying technical infrastructure and IT services required to support the overall strategy for steady corporate growth. An ineffective IT strategy may inhibit the ability of the Group to provide strong technological solutions in its markets. This will therefore affect company's competitiveness, quality and operational efficiency, ultimately affecting customer numbers, income and profitability.

2. Growth Strategy. The strategic positioning of the Group combines its own products with strong multi-channel sales and diversification across destinations. The Group focuses on improving its competitiveness, expanding the range of tourism products, and on developing digital platforms in new markets and destinations. The optimal asset utilization of aircraft, cruise ships and hotels is critical to the financial success of the Group, especially in a growth phase. There is a risk that the Group will not be able to achieve some initiatives and hence the overall growth.

3. Integration \& Restructuring Opportunities. The key strategic paradigm of the Group is to act 'as one' wherever possible, particularly through group platforms and across the markets, while maintaining local differences, since the benefits of such differentiation are greater than those of harmonization. Currently, there are a number of restructuring projects being implemented under an active program of acquisitions (e.g., Hotelbeds) and business sales (e.g., Boomerang Reisen and Berge \& Meer) with associated integration projects. With restructuring or integration programs, management risks arise that relate to further business integration and reduction of 
ENTREPRENEURSHIP AND SUSTAINABILITY ISSUES

ISSN 2345-0282 (online) http://jssidoi.org/jesi/

2020 Volume 8 Number 2 (December)

http://doi.org/10.9770/jesi.2020.8.2(78)

Make your research more visible, join the Twitter account of ENTREPRENEURSHIP AND SUSTAINABILITY ISSUES: @Entrepr69728810

duplicating factors. Apart from those, there may be challenges in developing an operating model that is more rational and optimized.

4. Corporate \& Social Responsibility. For the Group, economic, environmental and social sustainability is a fundamental principle of management and a cornerstone of a strategy for continuously adding value to the company. Therefore, the Group creates the conditions for long-term economic success and takes responsibility for sustainable development in the tourism industry. The company's initiatives are to reduce the environmental footprint of tourism directly, through its own business, and indirectly, through the influence on partners in the supply chain, thereby yielding a positive impact on the quality of life in tourist destinations, their stable growth and development. There is a risk that the company will fail to achieve some initiatives and efficiently manage tourism if suppliers do not comply with its corporate and social responsibility standards. If the Group fails to maximize its positive impact on tourism destinations and minimize the negative impact to the extent that its stakeholders expect, this could result in a confidence decline, reputational damage, decrease in demand, and loss of competitive advantage. Furthermore, if the Group fails to achieve its sustainable development goals and put them in line with those in the UN Paris Climate Change Agreement (December 2015), this could lead to sustained long-term damage to its structure and strategic destinations.

5. Information Security. The Group is responsible for protecting the confidentiality, integrity, and availability of information provided to customers, employees, suppliers, and service delivery teams. This dynamic risk is associated with the increase of global cybercrime activities and new regulations (e.g., the European Union's General Data Protection Regulation). At the same time, consolidation under the TUI brand and growing dependence on online sales and customer care channels (web/mobile devices) increase corporate exposure to cyber attacks and hacks. If the Group does not provide an appropriate level of security control in the corporate system, this could have a negative impact on the interaction with key stakeholders, reputational damage and potential for undesirable financial consequences.

6. Impact of Brexit. The major challenge of the Group is to restrict the airline access to the EU airspace, particularly German and Spanish. This would affect the company's operational and financial activities. Furthermore, the scope of uncertainty includes the status of the UK partners and colleagues and new visa requirements for organizing trips from the UK to the EU.

7. Impact of COVID-19. Responding to the global challenges of COVID-19, the Group decided to suspend the vast majority of travel-related operations, including package tours, cruises and hotel operations. This temporary suspension aims to facilitate the global government efforts to mitigate the proliferation of COVID-19. The major concern of the Group is to limit flights, which could have a strong operational and financial impact. 
ENTREPRENEURSHIP AND SUSTAINABILITY ISSUES

ISSN 2345-0282 (online) http://jssidoi.org/jesi/

2020 Volume 8 Number 2 (December)

http://doi.org/10.9770/jesi.2020.8.2(78)

Make your research more visible, join the Twitter account of ENTREPRENEURSHIP AND SUSTAINABILITY ISSUES: @Entrepr69728810

Operational risks to TUI Group (Tui Group, 2019c):

A. Destination Disruptions. With operations in international markets, the Group is exposed to the risk of unwanted incidents within the tourist destinations, particularly natural disasters such as hurricanes or tsunamis; outbreaks of disease such as COVID-19; the political volatility as has been seen in Egypt, Turkey, and Greece in recent years; war in countries close to company's markets and travel destinations; and terrorist events such as the tragic incident in Tunisia in 2015. There is a risk that if such an undesirable event occurs in a tourist destination, affecting one or several destinations, the Group may potentially suffer from significant operational disruption and increased costs.

B. Human Resources Management. The Group's success depends on its ability to attract, retain and develop talents to deliver high-quality tourism services. There is a risk that the Group will be unable to attract and retain skilled employees, create potential for future leadership capability, and maintain the commitment and trust of its employees. Problems of managing and maintaining human resources under the corporate strategy may negatively impact shareholder confidence and company's ability to maintain a corporate business model.

C. Customer Demand. Travel and tourism expenses are discretionary, price sensitive, and competitive. The economic prospects remain uncertain with various markets at different points in the economic cycle. Furthermore, the recent years saw an emergence of successful alternative business models such as travel websites and hotel portals which allow end consumers to independently combine the individual elements of a trip and book them separately. There is a risk that these external factors will affect the spending power of customers, resulting in slower growth and lower margins.

D. Input Cost Volatility. A significant portion of operating expenses are displayed in local currency and relate to the price of aircraft and cruise fuel, which therefore exposes the business to fluctuations through the volatility of exchange rates and fuel prices. There is a risk that if the Group does not adequately manage the volatility of exchange rates, fuel prices and other input costs, this could result in increased costs and lower margins, affecting the ability to achieve certain goals. There is also the risk that if the hedging policy is too rigid, the Group may not be able to respond to competitive pricing pressures during the tourist season. Furthermore, changes in macroeconomic conditions may influence the exchange rates and the translation of market results into the reporting currency of the Group.

E. Seasonal Cash Flow Profile. Tourism is a seasonal business with the majority of profits earned in the summer months. There is a risk that if the Group does not adequately manage its cash balances in the winter season, this could affect liquidity and the ability to settle liabilities as they mature, while ensuring that financial conditions are met.

F. Legal \& Regulatory Compliance. Most service providers operate across different countries and jurisdictions, which exposes them to a number of legal, tax and other regulatory laws that must be complied with. Operating across multiple source markets and in more than 115 destinations, the Group faces with a range of laws and regulations that must be complied with or else a risk of fines or other sanctions from regulatory bodies would emerge. 


\section{ENTREPRENEURSHIP AND SUSTAINABILITY ISSUES}

ISSN 2345-0282 (online) http://jssidoi.org/jesi/

2020 Volume 8 Number 2 (December)

http://doi.org/10.9770/jesi.2020.8.2(78)

Make your research more visible, join the Twitter account of ENTREPRENEURSHIP AND SUSTAINABILITY ISSUES: @Entrepr69728810

G. Health \& Safety. For all service providers, ensuring the health and safety of customers is of paramount importance. This is especially true for the Group, as it is a globally operating tourism company, which annually sells leisure to more than 21 million customers. There is a risk of accidents or incidents that could result in illness, injury or death to customers or colleagues on a trip. This may result in reputational damage to the business and/or financial liabilities.

H. Supplier Reliance. Travel service providers are exposed to the risk of failure in their main suppliers, especially if the tourism services are integrated. This is aggravated by the industry convention on prepayments for hoteliers to ensure a secure distribution of rooms during the season as well as in areas where one supplier is used to provide a product or service. There is a risk that the Group will be unable to continue with its core business operations in the event of a major service failure from its key suppliers.

I. Joint Venture Partnerships. Travel and tourism groups normally use joint venture partnerships within their operations in order to reduce the risk of new ventures or to gain access to additional intellectual resources or innovations. The TUI Group consists of three large joint ventures: Riu, TUI Cruises and Sunwing. There is a risk that if the Group does not maintain effective relationships with its key partners or if their goals do not meet those of the Group, this could lead to operational difficulties and jeopardize the achievement of financial targets.

The results of risk assessment reveal that the Group may use risk diversification to ensure internal and external flexibility in conditions of global economic uncertainty. Technological solutions for global governance within the international tourism network are blockchain-based and enable synergy among the tourism market participants. Building interactions between participants in a regional ecosystem facilitates the innovative growth of the company in relation to its global and local dimensions. Recent studies show that synergistic effects of an innovation economy serve a unique hidden power, manifested only within open operations and in proactive cooperation. The efficiency of the regional innovation system is driven by many factors, from information security to transactional processes. The use of digital means helps reduce the human impact on the most communication processes, ensuring security and transparency of transactions. This is achievable through blockchain and smart contracts (Finogeev et al., 2018).

Blockchain technology has moved beyond the cryptocurrency and entrenched itself in various areas of international business (Hooper \& Holtbrügge, 2020). It is predicted that by 2030, 30 percent of the global customer base will be constituted by entities using blockchain as a basic technology for conducting business activities [Gartner, 2017]. Going forward, the commercial use of blockchain will move from the experimental stage to presenting solutions to real problems, when large companies realize that it can be used to find solutions to current problems. This technology will provide many potential applications for cross-industry use that will impact contracts, transportation, payments and supply chain management (Floyd, 2018).

Blockchain is rapidly being adopted in financial institutions and banks, as well as in many other companies such as Samsung, Deloitte, RWE and IBM, with applications ranging from simplifying and automating trade finance to creating decentralized markets for electricity trading (Buterin, 2016). In addition, blockchain is used as a payment alternative to credit cards or PayPal for e-commerce and international transfers (Antonopoulos, 2017).

Blockchain is a kind of digital ledger or database that stores immutable records of all operations and transactions, all information about which is stored on the network (Drescher, 2017). Blockchain is a new type of database in which a distributed group of people can validate transactions and data in a way that does not require a centralized 


\section{ENTREPRENEURSHIP AND SUSTAINABILITY ISSUES}

ISSN 2345-0282 (online) http://jssidoi.org/jesi/

2020 Volume 8 Number 2 (December)

http://doi.org/10.9770/jesi.2020.8.2(78)

Make your research more visible, join the Twitter account of ENTREPRENEURSHIP AND SUSTAINABILITY ISSUES: @Entrepr69728810

third party and does not require them to trust each other. These data are stored in the blockchain and remain there publicly (Chirls, 2018).

Blockchain technology transforms traditional business activities by streamlining processes, increasing trust, and saving time and costs for companies (D. Tapscott \& A. Tapscott, 2016). Automating processes and saving time with smart contracts make business more efficient and eliminate the need for bureaucratic procedures associated with organizing business processes (Torres de Oliveira, 2017). In addition, the risks associated with fraud and data security are reduced, since data no longer need to be transferred or managed by centralized organizations (Hooper \& Holtbrügge, 2020).

The use of blockchain technologies affects the management of the international activities of companies on a global scale, changing traditional business processes and methods of cross-border transactions and allowing companies to operate in a decentralized mode (Hooper \& Holtbrügge, 2020).

The blockchain technology has great potential to generate a fundamentally new mechanism for digital management. Research on blockchain applications in various fields revealed that the use of blockchain in international business is differential to global governance, enables the reduction of transaction costs and reliable protection of intellectual property rights (Hooper \& Holtbrügge, 2020).

Blockchain technology provides significant benefits for the travel industry, as its implementation can help increase the competitive advantage of companies, increase customer satisfaction and productivity (Erceg et al., 2020). The use of blockchain technology in tourism can lead to lower costs associated with exchange rates and has great potential to simplify travel loyalty programs (Kowalewski et al., 2017).

Blockchain is multifaceted, and its application will improve tourism in several ways: (i) improve the travel experience by supporting the platform; (ii) cross-border payments through the blockchain are fast and reliable; (iii) the use of blockchain offers diversification, with which it protects the currency and strengthens the banking system; and (iv) blockchain can help reduce overall operating costs (Kwok \& Koh, 2019).

In 2018, the TUI Group revealed a new revolution within its business development, embedding blockchain into its business model. The company tested blockchain by tracking internal operations with the aim of further expanding the scope of this technology to other processes. As per now, the company rolls out a pilot blockchain-powered project named BedSwap that allows recording hotel inventories (Kondratiuk, 2017).

The integration of global governance model with the TUI Group's partnership system (Figure 2) would make it possible to innovate and diversify tourism offerings through a cultural dimension of corporate management. The integration may generate a universal form of partnership based on corporate values and synergies as well as organizational and technological elements that are clearly defined. 
Make your research more visible, join the Twitter account of ENTREPRENEURSHIP AND SUSTAINABILITY ISSUES: @Entrepr69728810

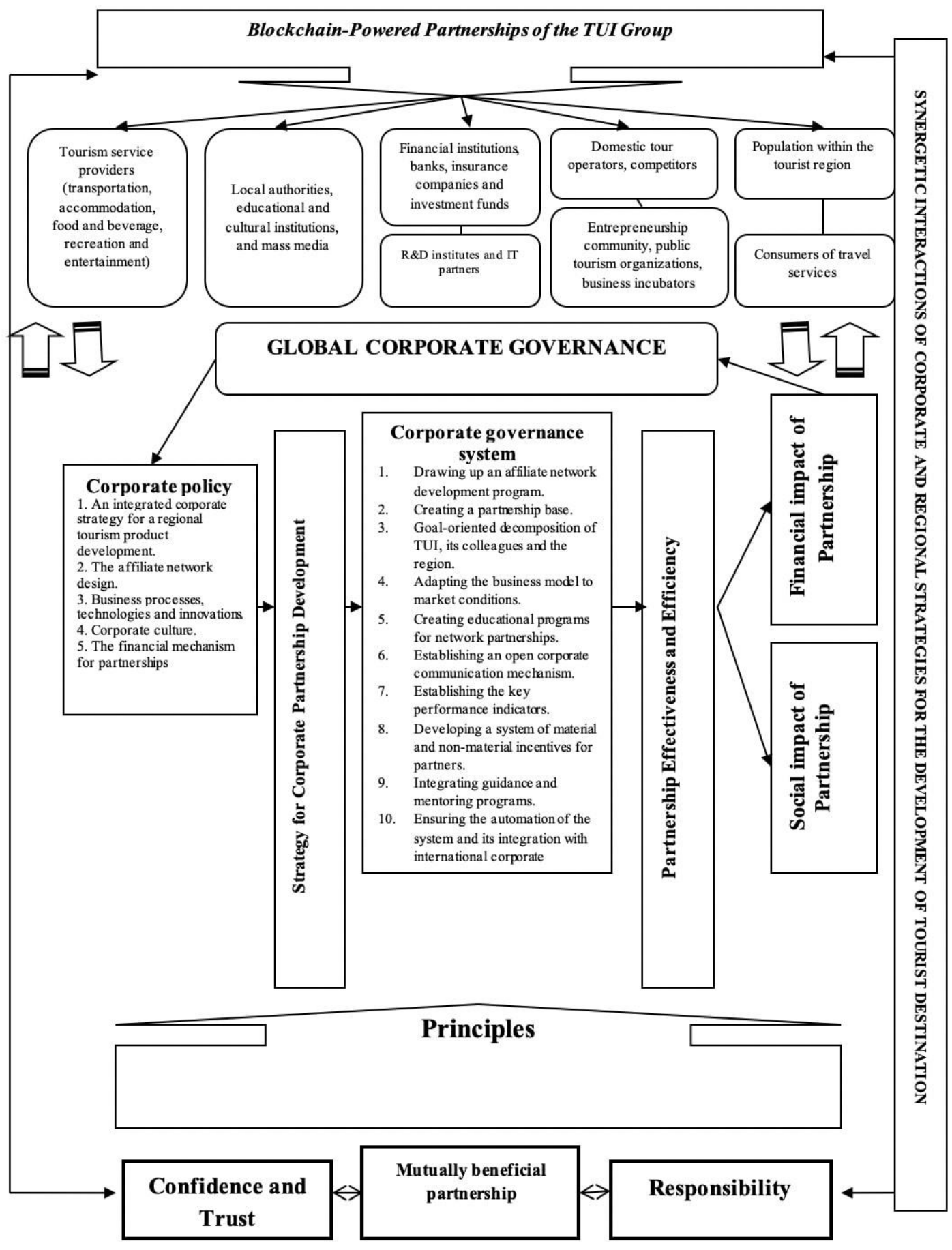

Figure 2. The TUI Group's Blockchain-Based Model of global governance. Source: developed by the authors 
Make your research more visible, join the Twitter account of ENTREPRENEURSHIP AND SUSTAINABILITY ISSUES: @Entrepr69728810

As the information space and the loyalty systems of transport operators and hoteliers grow, tourism services became available to a broader range of consumers, entailing a mass refusal from the comprehensive travel services. A modern-day tourist adheres to democracy, independence and individualism in his journey-related decisions, which traditional service providers fail to ensure. In this regard, the tourism industry is undergoing significant changes of consumer demand towards new and creative. Thereby, the expansion into new markets and tourist destinations would provoke sustainability in transformation processes (Edgell, 2016). Meanwhile, various tour developers seek to portray the socio-cultural identity of tourist destinations.

The integration of global governance strategy into the corporate policy of the Group permits the sustainable tourism development, whilst shaping the international eco-friendly business model. The regional socio-economic effects of this strategy are shown in Figure 3.

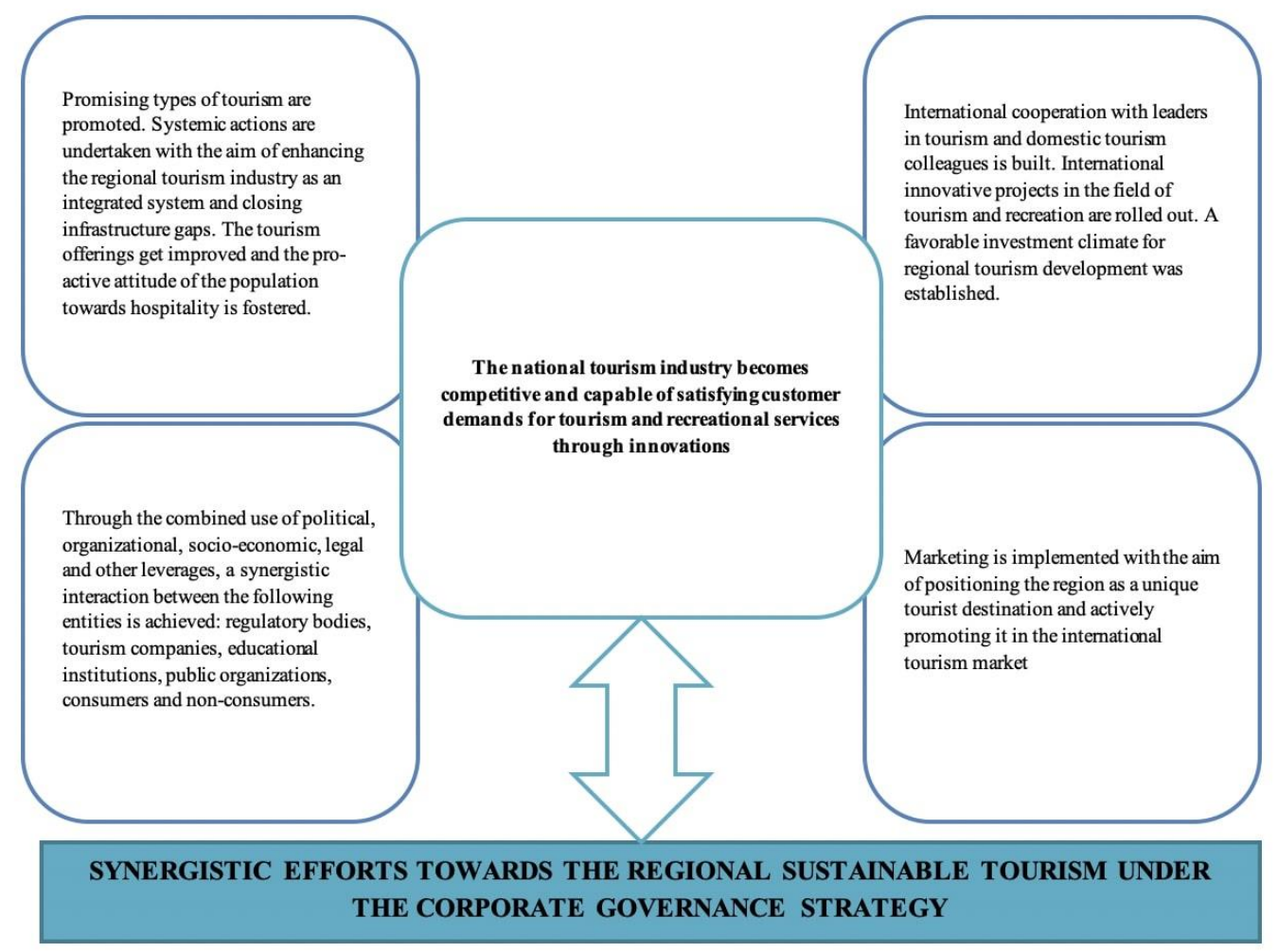

Figure 3. The socio-economic impact of employing the global governance strategy on the generation of competitive tourism products, Source: developed by the authors

With globalization, the instability in business and project management has increased. Many internal and external factors influence the successful implementation of global projects of multinational companies. Organizational culture, socio-economic factors, inter-ethnic culture and senior management attitudes affect the work of a global project team (Bhullar, 2018). In international business, attention is mainly focused on the direct impact of international diversification on the profit or risk of firms, and little attention is paid to the impact of locations where internationalization activities have taken place (Harjito et al., 2018). 


\section{ENTREPRENEURSHIP AND SUSTAINABILITY ISSUES}

ISSN 2345-0282 (online) http://jssidoi.org/jesi/

2020 Volume 8 Number 2 (December)

http://doi.org/10.9770/jesi.2020.8.2(78)

Make your research more visible, join the Twitter account of ENTREPRENEURSHIP AND SUSTAINABILITY ISSUES: @Entrepr69728810

The success of the TUI Group largely depends on the success of global projects. Cross-border cultural diversification has a significant impact on the company's operations. In this regard, the company's interaction with regional representatives of the tourism market and the interweaving of development strategies allow improving the quality of the tourism product and providing the TUI Group with a competitive advantage in the global business scenario.

\section{Discussion}

The global instability and uncertainty necessitate a fundamentally new approach towards thinking and international interaction to manage public relations more efficiently, whilst reducing environmental footprint. Issues such as globalization and social policy management have been opened up for discussions in the last decade. The latter was regarded from the perspective of multicentricity where the concept of global governance went beyond intergovernmental institutions, was socially oriented and globally inclusive (Unlu, 2017). Meta-economic approaches to management in the context of globalization were determined with a focus laid on those frameworks for global governance that were aimed at sustainability, competitiveness, and innovation-driven economic growth (Buracas, 2018).

The concept of global governance was previously disclosed by the members of the Club of Rome with the aim of solving the global problems of social development and socio-economic relationship building. In 1968, the Club of Rome established a global forecasting, modeling and programming system. At the end of 2017, the Club members published a sensational report entitled 'Come on! Capitalism, Short-termism, Population and Destruction of the Planet.' This report proclaims that the Old World is doomed and a New World is inevitable (von Weizsacker \& Wijkman, 2017). The new concept of global development calls for the rejection of materialism, financial speculation and capitalism. The report emphasizes the need for a philosophical approach towards the current world crisis. The authors refer to the initiative of the Pope and the UN approach articulated in the 2030 Agenda for Sustainable Development (United Nations, 2015).

Joining international tourism alliances and networks can enhance the innovative potential of tourism agencies through the expansion into new markets and the adoption of new technologies and value chains. However, the benefits from cooperation are intertwined with regulatory compliance that is crucial to competitiveness in the global tourism market. Studies revealed a negative impact of transnational tourism management, concluding a need for counteracting the negative influences of globalization (Mishulina, 2016). It is a justified recommendation to improve the mechanism for minimizing the negative environmental impact and associated socio-economic effects from large investment projects in the field of tourism and recreation (Molchanova, 2018).

The collaboration with single economies and global industries is a key to the acquisition of competitive advantages in the international arena. Global governance refers to the meaningful, process-oriented and polycentric actions and interactions between global actors having direct or indirect influence on international relations through the use of economic instruments, methods and mechanisms (Barry, 2001). Moreover, global governance goes beyond the boundaries of the national state and covers a network of diverse business-public interactions (General Assembly of the United Nations, 2010). 


\section{ENTREPRENEURSHIP AND SUSTAINABILITY ISSUES}

ISSN 2345-0282 (online) http://jssidoi.org/jesi/

2020 Volume 8 Number 2 (December)

http://doi.org/10.9770/jesi.2020.8.2(78)

Make your research more visible, join the Twitter account of ENTREPRENEURSHIP AND SUSTAINABILITY ISSUES: @Entrepr69728810

\section{Conclusions}

The rapid pace of transnationalization caused the international economic relations to transform. As a result, a range of new approaches to corporate governance in the global tourism sector have emerged that are based on the interdependence of national economies. The analysis of management and operational risks in the TUI Group strategy for global governance revealed that the Group may use risk diversification to ensure internal and external flexibility in conditions of global economic uncertainty. The risk likelihood assessment showed the need for the adoption of innovative management models to reduce the likelihood and impact of risks. The use of digital solutions will reduce the human impact on most communication processes, ensuring the security and transparency of transactions between economic agents.

The integration of blockchain-based global governance into the partnership system of the Group will make it possible to innovate and diversify tourism offerings through a cultural dimension of corporate management. The integration may generate a universal form of partnership based on corporate values and synergies as well as organizational and technological elements that are clearly defined. The expansion into new markets and tourist destinations was found to precondition sustainability within the Group's transformation processes. The analysis of socio-economic benefits from implementing the TUI Group's strategy for global governance to expand destination experience confirms the contribution to sustainable and eco-friendly international tourism.

\section{References}

Antonopoulos, A. (2017). Mastering Bitcoin: Unlocking Digital Cryptocurrencies. 2nd ed., London: O'Reilly

Barry, T. (2001). Global Economic Governance: Strategic Crossroads. Foreign Policy in Focus. Retrieved July 26, 2020 from https://fpif.org/global_economic_governance_strategic_crossroads/

Bhullar, P.S. (2018). Global Project Management - Challenges and Barriers. Asian Journal of Management, 9(1), 717-722. http://dx.doi.org/10.5958/2321-5763.2018.00111.7

Buracas, A. (2018). Metaeconomic Approaches in Global Governance. In A. Karasavvoglou, S. Goić, P. Polychronidou, \& P. Delias (Eds.), Economy, Finance and Business in Southeastern and Central Europe (pp. 611-619). Cham: Springer.

Buterin, V. (2016). What is Ethereum?, Coincenter. Retrieved July 26, 2020 from https://coincenter.org/entry/what-is-ethereum

Chirls, N. (2018). Blockchain \& the Decentralization of Finance Featured Session at SXSW 2018, Video. Retrieved July 26, 2020 from https://www.sxsw.com/interactive/2018/blockchain-and-the-decentralization-of-finance-featured-session-at-sxsw-2018/

Dangi, T.B., \& Jamal, T. (2016). An Integrated Approach to "Sustainable Community-based Tourism”. Sustainability, 8, $475-507$. https://doi.org/10.3390/su8050475

Dovgal, G.V. (2014). The Evolution of Transnationalization in the Global Tourism Business. Journal of V.N. Karazin Kharkiv National University, 1144, 162-165.

Drescher, D. (2017). Blockchain Basics: A Non-Technical Introduction in 25 Steps. New York: Apress.

Duginets, G.V. (2017). Transnationalization of the World Tourism Market. Market Infrastructure, 9, 123-128.

Edgell, S. (2016). Managing Sustainable Tourism: A Legacy for the Future. London: Routledge. 


\section{ENTREPRENEURSHIP AND SUSTAINABILITY ISSUES}

ISSN 2345-0282 (online) http://jssidoi.org/jesi/

2020 Volume 8 Number 2 (December)

http://doi.org/10.9770/jesi.2020.8.2(78)

Make your research more visible, join the Twitter account of ENTREPRENEURSHIP AND SUSTAINABILITY ISSUES: @Entrepr69728810

Erceg, A., Sekuloska, J.D., \& Kelić, I. (2020). Blockchain in the Tourism Industry-A Review of the Situation in Croatia and Macedonia. Informatics, 7, 5. https://doi.org/10.3390/informatics7010005

Finogeev, A.G., Gamidullaeva, L.A., Vasin, S.M., Finogeev, A.A., Pronichev, V.V., \& Lychagin, K.A. (2018). Smart Contracts as a Tool for Safe Interaction of the Regional Innovation Subjects. Social Sciences. Economics, 3(47), 139-157.

Floyd, D. (2018). Deloitte: 3 Out of 4 Big Companies See 'Compelling' Case for Blockchain. Coindesk. Retrieved July 26, 2020 from https://www.coindesk.com/deloitte-3-out-of-4-big-companies-see-compelling-case-for-blockchain

Gartner (2017). Talari Networks. Blockchain WAN Edge = Leading the Digital Transformation. Gartner. Retrieved July 26, 2020 from https://www.gartner.com/imagesrv/media-products/pdf/Talari-Networks/talarinetworks-1-4A5JDFW.pdf

General Assembly of the United Nations. (2010). Integrated and Coordinated Implementation of and Follow-up to the Outcomes of the Major United Nations Conferences and Summits in the Economic, Social and Related Fields. Retrieved July 26, 2020 from http://www.un.org/en/ga/62/plenary/followupconf/bkg.shtml

Han, Y., Shao, X.F., Cui, X., Yue, X.G., Bwalya, K.J., \& Manta, O. (2019). Assessing Investor Belief: An Analysis of Trading for Sustainable Growth of Stock Markets. Sustainability, 11(20), 5600. https://doi.org/10.3390/su11205600

Harjito, A., Bany-Ariffin, A.N., Matemilola, B., \& Ashari, M. (2018). International Diversification and Multinational Firms' Risk: Do Locations of Investments Matter?. International Journal of Economics \& Management, 12(1), 357-368.

Hooper, A., \& Holtbrugge, D. (2020). Blockchain Technology in International Business. Changing the Agenda for Global Governance. Review of International Business and Strategy. https://dx.doi.org/10.1108/RIBS-06-2019-0078

Kondratiuk, A. (2017). The Europe's Largest Tour Operator Will Use Blockchain for Internal Operations. Forklog. Retrieved July 26, 2020 from https://forklog.com/krupnejshij-turoperator-evropy-zadejstvuet-blokchejn-dlya-vnutrennih-operatsij/

Kowalewski, D., McLaughlin, J., \& Hill, A.J. (2017). Blockchain Will Transform Customer Loyalty Programs. Retrieved July 26, 2020 from https://hbr.org/2017/03/blockchain-will-transform-customer-loyalty-programs

Kwok, A.O., \& Koh, S.G. (2019). Is blockchain technology a watershed for tourism development?. Current Issues in Tourism, 22(20), 2447-2452. https://doi.org/10.1080/13683500.2018.1513460

Mishulina, S.I. (2016). Mechanisms for Minimizing the Negative Environmental, Economic and Social Effects of Investment Projects. Science Review, 8, 170-177.

Molchanova, V.A. (2018). The Impact of Globalization on the Tourism Sector: Conceptual Approaches. Russian Journal of Entrepreneurship, 12, 3812-3826.

Shao, X.F., Gouliamos, K., Luo, B.N.F., Hamori, S., Satchell, S., Yue, X.G., \& Qiu, J. (2020). Diversification and Desynchronicity: An Organizational Portfolio Perspective on Corporate Risk Reduction. Risks, 8(2), 51. https://doi.org/10.3390/risks8020051

Skarga, O.O. (2018). Areas for the Integration of Ukraine Into the World Tourism Market in the Context of Globalization. Economic Domain, 130, 36-49.

Sun, S., Li, T., Ma, H., Li, R.Y.M., Gouliamos, K., Zheng, J., Han, Y., Manta, O., Comite, U., Barros, T., Duarte, N., \& Yue, X.G. (2020). Does employee quality affect corporate social responsibility? Evidence from China. Sustainability, 12(7), 2692. https://doi.org/10.3390/su12072692

Tapscott, D., \& Tapscott, A. (2016). Blockchain Revolution: How the Technology Behind Bitcoin Is Changing Money, Business, and the World. New York: Portfolio.

Torres de Oliveira, R. (2017). Institutions, Middleman, and Blockchains. Shuffle and Re-Start. Working Paper, University of Queensland Business School. http://dx.doi.org/10.2139/ssrn.3027633 
ENTREPRENEURSHIP AND SUSTAINABILITY ISSUES

ISSN 2345-0282 (online) http://jssidoi.org/jesi/

2020 Volume 8 Number 2 (December)

http://doi.org/10.9770/jesi.2020.8.2(78)

Make your research more visible, join the Twitter account of ENTREPRENEURSHIP AND SUSTAINABILITY ISSUES: @Entrepr69728810

Tui Group. (2019a). Annual report Tui Group. Retrieved July 26, 2020 from http://annualreport2019.tuigroup.com/sites/default/files/downloads/tui_annual_report_2019.pdf

Tui Group. (2019b). Combined Management report Tui Group. Retrieved July 26, 2020 from http://annualreport2019.tuigroup.com/sites/default/files/downloads/tui_ar_management_report_2019.pdf

Tui Group. (2019c). Corporate Governance Tui Group. Retrieved July 26, 2020 from http://annualreport2019.tuigroup.com/sites/default/files/downloads/tui_ar_corporate_governance_2019.pdf

United Nations. (2015). Transforming Our World: The 2030 Agenda for Sustainable Development. Retrieved July 26, 2020 from https://sustainabledevelopment.un.org/content/documents/21252030\%20Agenda\%20for\%20Sustainable\%20Development\%20web.pdf

Unlu, A.D. (2017). Global Governance Vs. Regional Governance in Social Policy. Handbook of Research on Technology Adoption, Social Policy, and Global Integration. IGI Global. London: Routledge.

von Weizsacker, E.U., \& Wijkman, A. (2017). Come on!: Capitalism, Short-termism, Population and the Destruction of the Planet. Cham: Springer.

\section{Biographical note:}

Asad H. ABURUMmaN is an Associate Professor at the University of Sharjah, UAE. Research interests: tourist guides; communication skills in tourism industry; heritage protection and its use for tourism purposes; tourist and guest behavior; laws and legislation in tourism; hospitality management; public relations in tourism; human resources management in tourism; knowledge management capabilities in tourism organizations; organizational behavior; quality management in tourism; creative ability of business; tourism and hotel marketing; tourism industry; hotel management; customer relationship management; hospitality technology.

ORCID ID: orcid.org/0000-0001-5495-5572

Copyright (C) 2020 by author(s) and VsI Entrepreneurship and Sustainability Center

This work is licensed under the Creative Commons Attribution International License (CC BY).

http://creativecommons.org/licenses/by/4.0/

(c) (i) Open Access 